\title{
Situation Awareness of Cough Etiquettes of Hospital Security Personnel and Janitors
}

\author{
${ }^{*}$ Kusbaryanto $^{1}$, Listiyowati ${ }^{2}$
}

\begin{abstract}
Nosocomial infection is a major problem in hospitals around the world. To minimize the risk of infection in hospitals and other healthcare facilities, cough etiquette has to be applied. Thus, good situation awareness and the understanding why cough etiquette is important are necessary. The purpose of this study was to find out the effective education on cough etiquette on hospital security personnel's and janitors' situation awareness on cough etiquette. This research study followed quasy experimental design with pretest and post test control group design. The sampling technique was purposive sampling involving 24 respondents for experimental group and 27 respondents for the control group. The analysis of the data employed Wilcoxon test and it employed Mann Whitney test to find out the difference of independent variable medians. Questionnaires were used to gather data collection. The result of the analysis presented a mean of 97.7 on the post-test of control group and a mean of 116.3 on the post-test of treatment group. Wilcoxon and Mann Whitney tests resulted $p=0.001(<0.05)$, which meant there were significant differences. Education on cough etiquette is effective to raise hospital security personnel and the janitors' awareness on cough etiquette situation.
\end{abstract}

Keyword: Situation awareness, cough etiquette, hospital security, janitors

\section{INTRODUCTION}

Nosocomial infection is a major problem in hospitals around the world. The prevalence of nosocomial infections in developing countries is two to three times higher than in Europe or America. The incidence of nosocomial

1. ${ }^{*}$ Dr. Kusbaryanto, MKes, lecturer, Department of Public Health and Family Medicine, Universitas Muhammadiyah Yogyakarta. Email: kusbaryanto@umy. ac.id

2. Dr. Ekorini Listiyowati, MMR, Lecturer, Department of Public Health and Family Medicine, Universitas Muhammadiyah Yogyakarta

${ }^{*}$ For correspondence infections in intensive care units is higher than the other units. ${ }^{1}$ Nosocomial infection may lead to the additional cost that the infected patient has to pay and may lead to additional time the patient has to stay. Nosocomial infections may occur because of the use of ventilator in pneumonic patients, infection of the blood vessels, urinary tract infections and infections due to surgery. ${ }^{2}$

To minimize the risk of infection occurs in hospitals and other health care facilities, prevention and infection controls have to be applied, which cover planning, implementation, consultation, education and training, and monitoring and evaluation. ${ }^{3}$ Concrete manifestation of these efforts is the application of standard precautions. The application of standard precautions is expected to reduce the risk of pathogen transmission from known and unknown source.

In the application of standard precautions, there are several things to consider which are hand hygiene, the use of gloves, eye protection (covering face, nose, mouth), protective suit, needle and other sharp objects of wound prevention, respiratory hygiene or cough etiquette, environmental hygiene, linen, waste disposal and patient care equipment. ${ }^{4}$

Cough etiquette is one component of standard precautions meant to prevent the transmission of microorganism that cause respiratory tract infections that high level of health care ${ }^{5}$. When a persons exposed to a respiratory tract, coughing or sneezing, that person will excrete droplet-shaped disease particles containing viruses or microorganisms that, when entered into the respiratory tract of other people, may cause infection as well. ${ }^{6}$

Livnat et al $(2007)^{7}$ reveal that there are three levels of situation awareness. The first one is perception of all aspects in the environment, namely the basic knowledge or the understanding of the environment obtained through sight, touch and feeling. The second is comprehension which is the ability to analyze the collection or integration of the received of various information. The third is projection, which is the ability to predict future environmental conditions based on information and data received. 
Situation awareness has been recognized as an important variable and all divisions require it for performance enhancement. Situation awareness is to know and aware of the circumstances covering the place and the job. ${ }^{8}$ A study is needed to investigate effective methode to improve the situation awareness. The method may various dependent on the local habits and culture. The purpose of this study was to find out the effective education of hospital security personnel's and janitors situation awareness regarding cough etiquette. Thus, improving situation awareness to cough etiquette would reduce spreading of microorganism in the hospital.

\section{MATERIALS AND METHODS}

This research followed study quasy experimental design with pretest and posttest control group design9. The sampling technique was purposive sampling involving 24 respondents for experimental groups and 27 for control groups. The analysis of the data employed Wilcoxon test and it employed Mann Whitney test to find the difference of independent variable medians. Questionnaires were used to gather collect data.

\section{RESULTS}

The results measurement of the situation awareness in the control group, mean 103,9 and SD 98,4 and in the treatment group, mean 104,92 and SD 10,84 differences of situation awareness in the control group before and after treatment was $p=0.015(>0.05)$, the result was not significan. Differences of Situation awareness in the treatment group before and after treatment was $p=0.003$ $(<0.05)$, the result was significant differences of situation awareness in the control group and treatment group after treatment was $\mathrm{p}=0.001(<0.05)$, the result was significant.
The results measurement of the age of respondent (table 1) by chi square test, $\mathrm{p}=0.782$, this data were homogenously distributed.

Table-1: Age of respondents

\begin{tabular}{|l|c|c|c|c|}
\hline \multirow{2}{*}{ Variables } & \multicolumn{2}{|c|}{ Control Group } & \multicolumn{2}{c|}{ Treatment Group } \\
\cline { 2 - 5 } & Frequency & Percentage & Frequency & Percentage \\
\hline$<20$ & 2 & 7.4 & 1 & 4.2 \\
\hline $20-30$ years & 14 & 51.9 & 10 & 41.7 \\
\hline $31-40$ years & 9 & 33.3 & 10 & 41.7 \\
\hline$>40$ years & 2 & 7.4 & 3 & 7.4 \\
\hline
\end{tabular}

p $0.782^{* *}$

**Not Significant $(\mathrm{p}>0.05)$

Table-II: Respondents employing time

\begin{tabular}{|l|c|c|c|c|}
\hline \multirow{2}{*}{ Variables } & \multicolumn{2}{|c|}{ Control Group } & \multicolumn{2}{c|}{ Treatment Group } \\
\cline { 2 - 5 } & Frequency & Percentage & Frequency & Percentage \\
\hline$<1$ & 6 & 22.2 & 7 & 29.2 \\
\hline $1-5$ years & 20 & 74.1 & 16 & 66.7 \\
\hline$>5$ years & 1 & 3.7 & 1 & 4.2 \\
\hline
\end{tabular}

p $0.841^{* *}$

${ }^{* *}$ Not Significant $(\mathrm{p}>0.05)$

The results measurement of the age of respondent (Table I) by chi square test, $\mathrm{p}=0.841$, this data were homogenously distributied.

Table-III : Differences of situation awareness between Control Group and Treament Group

\begin{tabular}{|c|c|c|c|c|c|c|c|}
\hline \multirow[t]{2}{*}{ Variable } & \multicolumn{3}{|c|}{ Control Group } & \multicolumn{3}{|c|}{ Treatment Group } & \multirow{2}{*}{$\frac{\mathrm{P}}{\text { Value }}$} \\
\hline & $\mathrm{n}$ & Mean & SD & $\mathrm{n}$ & Mean & $\mathrm{SD}$ & \\
\hline $\begin{array}{l}\text { Situation Awareness of before } \\
\text { treatment }\end{array}$ & 27 & 103.9 & 8.4 & 24 & 104.92 & 10.84 & \\
\hline $\begin{array}{l}\text { Situation Awareness after } \\
\text { treatment }\end{array}$ & 27 & 97.7 & 9.6 & 24 & 116.3 & 12.75 & $0.001^{*}$ \\
\hline $\mathrm{p}$ & \multicolumn{3}{|c|}{$0.015^{* *}$} & \multicolumn{3}{|c|}{$0.003^{*}$} & \\
\hline
\end{tabular}

*Significant $(\mathrm{p}<0.05)$

${ }^{* *}$ Not Significant $(\mathrm{p}>0.05)$ 


\section{DISCUSSION}

After educating, hospital security officers and janitors situation awareness on cough etiquette had increased. Their awareness had risen because of they had acquired the educational materials. The educational materials served as positive reinforcement and as stimuli for situation awareness of cough etiquette. ${ }^{10}$

Infectious diseases are easily transmitted through respiratory systems in a form of droplet. It also can be transmitted through a contact with such fluid entering through then nose, mouth and eyes. One of the preventions is by making such droplets not spreading. Thus, Centre of desease Control and prevention has urged to apply cough etiquette. ${ }^{11}$

Since the end of the Second World War, coughing and sneezing have been a big concern. Now handkerchief is no longer the theme to deal with coughing and sneezing. Now, chough etiquette has become the an alternative to prevent the spread of diseases being transmitted through breathing. Some serious illnesses such as influenza, Respiratory Syncitial Virus (RSV), SAR transmitted through coughing and sneezing, as well as through unhygienic and which come in contact with contaminated material. $^{12}$

\section{CONCLUSIONS}

On this basis, we conclude that education on cough etiquette with lecture was effective to improve hospital security personnel and the janitors situation awareness on cough etiquette, the significance was 0.001 .

\section{ACKNOWLEDMENT}

The research was supported by the Universitas Muhammadiyah Yogyakarta, author thank to the research grant from department of hospital management school of postgraduate studies Universitas Muhammadiyah Yogyakarta.

\section{REFERENCES}

1. Naidu, K., Nabose, I,. Ram, S, Viney, K,. Graham,S.M dan Bissell, K. 2014. A Descriptive Study of Nosocomial Infections in an Adult Intensive Care Unit in Fiji: 2011-12. Journal of Tropical Medicine, Article ID 545160.

2. Joram, N., Blaquat, N.D.S., Stam, D,. Launay, E,. Guen, C.G.L. 2012. Healthcare- Associated Infection Prevention in Pediatric Intensive Care Unit : a Review. Eur J Clean Microbiol Infec Dis, 31 : 2481-90.
3. Depkes. 2007. Guideline of Control and Prevention of Infection Control in Hospital and the other Health Services (Pedoman Pencegahan dan Pengendalian Infeksi di Rumah sakit dan Fasilitas Kesehatan lainnya. Depkes RI, pp 3-1.

4. WHO, 2007. Standard precaution. Acceesed on April 2016 from http:/www.who.int/csr/resources/ publications/EPR_AM2_E7.pdf

5. CDC. 2012. Respiratory Hygiene/Cough Etiquette in Healthcare Settings. Acessed on April 2016 from http://www.cdc.gov/flu/professionals/infectioncontro 1/resphygiene.htm

6. MyVMC, 2016. Cough and sneeze etiquette. Acessed on April 2016 from http://www.myvmc.com /lifestyles/cough-and-sneeze-etiquette.

7. Livnat, Y., Agutter, J., Moon, S dan Foresti, S. 2007. Visual Correlation for Situation Awareness. Acessed on Pebruari 2013 from www.cs.utah.edu.

8. Basarahil, C.S.H. 2001. The Influence of Midwife Situation Awareness to IUD and Implant contraception Intention with Behavior Biliefs, Normative Biliefs dan Control Beliefe as a Determinant (Pengaruh Situation Awareness Bidan terhadap Intention dalam Pelayanan Kontrasepsi IUD dan Implant dengan Behavior Biliefs, Normative Biliefs dan Control Beliefe sebagai Determinan). Disertation, Library of Public Health Faculty Airlangga University.

9. Polit, D.F., dan Hungler, B.P. 1999. Nursing Research Principles and Methods. Lippincott Philadelphia New York Baltimore, 6 edition, pp 188.

10. Wei,L.T dan Yazdanifard, R. 2014. The impact of Positive Reinforcement on Employees' Performance in Organizations. American Journal of Industrial and Business Management, 9.

11. APIC,2013. Respiratory etiquette: in important behavior change. Acessed on Oktober 2017 from file://G:/Etika\%20batuk\%20jurnal/APIC-Respirato ry-Etiquette.pdf

12. CDC. 2012. Respiratory Hygiene/Cough Etiquette in Healthcare Settings.Acessed on April 2016, from http://www.cdc.gov/flu/professionals/infectioncontro 1/resphygiene.htm 